\title{
La influenza, una oportunidad para la prevención y el control
}

R ecientemente se ha difundido en los medios de comunicación el riesgo de una pandemia de influenza cuyos efectos en la población podrían ser desastrosos, y ante ello diversos gobiernos han aportado recursos económicos para fortalecer la vigilancia epidemiológica y la producción de vacunas y medicamentos antivirales.

Toda la constelación de los virus influenza de origen animal se ubican en las aves acuáticas, de las cuales es factible que se transmitan a aves o a otros animales domésticos, y, a través de un proceso de selección y adaptación, pueden adquirir la capacidad de infectar a otras especies animales, incluido el hombre. Este proceso puede suceder en cualquier momento y es más probable si los virus tienen una amplia distribución, por lo cual se debe tener disponibilidad inmediata de los recursos para enfrentar esta contingencia. ${ }^{1}$

Es importante aclarar que una epidemia de influenza aviar (una epizootia) no necesariamente causará una epidemia en humanos, ya que la transmisión de virus de aves a otros animales, entre ellos el hombre, es un evento poco común; a pesar de eso, los cambios geneticos que ocurren de manera natural en los virus pueden favorecer la aparición de virus altamente patógenos para diversos animales y el hombre. Por esta razon, la presencia de un virus altamente patógeno para las aves como es el subtipo H5N1, que actualmente se ha detectado en algunos paises de Asia y Europa, no indica forzozamente que se transmitirá al hombre; sin embargo, se han registrado algunos casos asociados con este subtipo, sobre todo en personas que conviven de cerca con aves domésticas; no obstante, los datos disponibles sugieren que este virus no tiene la capacidad de transmitirse eficientemente de una persona a otra. ${ }^{2-4}$ Es importante considerar por lo menos dos factores que facilitarían la aparición de una epidemia: la patogenicidad del virus, que está relacionada con su capacidad de infección, replicación y de causar enfermedad, y la transmisibilidad, que le permite al virus diseminarse de una persona a otra; al parecer la transmisibilidad no está ocurriendo eficientemente con el virus H5N1. ${ }^{5-9}$ En todo caso, la situación que ahora prevalece en el mundo debe considerarse como una alerta para pre- parar las acciones de intervención en caso de la ocurrencia de brotes en humanos en cualquier región del planeta, por lo cual es necesario fortalecer la vigilancia epidemiologia principalmente en las aves domésticas y silvestres, así como en personas con cuadros respiratorios; el diagnostico diferencial es conveniente para descartar otras infecciones respiratorias. Las medidas de control de la transmisión del virus de la influenza podrian ser similares a las que se llevaron a cabo para controlar la diseminación del agente causal del Sindrome Agudo Respiratorio Severo (SARS-Coronavirus), donde las medidas de vigilancia, prevención y control, y la colaboración internacional, coadyuvaron a detener la epidemia en sólo algunos meses.

Hay tres indicadores importantes que deben tomarse en cuenta para el inicio de una pandemia con virus de origen animal: a) el incremento de casos en aves asociados con virus de alta patogenicidad, b) el aumento de casos en humanos por efecto del mismo virus detectado en aves y c) la elevada transmisión del virus de persona a persona.

Ante la necesidad de tener una vacuna para proteger a la población contra un virus de origen animal, en este caso de aves (por ejemplo, el virus H5N1), se requerirán por lo menos algunos meses para su producción, evaluación y aplicación; esto significa que las vacunas disponibles son poco eficientes para proteger a la población de una epidemia causada por virus de origen animal. Las vacunas para uso en humanos tienen virus de la influenza humana principalmente de los subtipos $\mathrm{H} 1 \mathrm{y}$ $\mathrm{H} 3$, por lo que dificilmente protegerán contra otro subtipo de virus, en particular contra el H5N1 de aves.

A pesar de que en países desarrollados está disponible la vacuna contra virus endémicos de la influenza humana, en la mayoría de los que están en vías de desarrollo esta opción es limitada. ${ }^{10-11}$ Por otro lado, en una situación de emergencia es previsible que los países productores de vacunas y medicamentos antivirales puedan limitar su venta a las naciones demandantes. En la actualidad, no hay una vacuna disponible para proteger a la población contra el virus de influenza aviar H5N1; sin 
embargo, algunos países están evaluando la vacuna en animales de experimentación. En este sentido es importante que México y otros naciones de Latinoamérica fortalezcan su capacidad para producir esta vacuna con el apoyo técnico y financiero de los países productores. A este respecto es importante resaltar los acuerdos internacionales que se tomaron en la reciente reunión de ministros de salud de varios países, en Ottawa, Canadá, donde se acordó confrontar la actual epizootia y fortalecer la colaboración internacional.

Las actividades de vigilancia epidemiológica y control de la influenza aviar deberían enfocarse principalmente en las granjas avícolas por la alta factibilidad de detectar virus de alta patogenicidad en las aves. En México existen cerca de 4000 granjas donde se producen alrededor de 260 millones de aves para consumo en cada ciclo reproductivo. No sólo deberá tener prioridad la vigilancia en el personal que trabaja en las granjas y en el que está en contacto directo con las aves, sino también la aplicación de vacunas y tratamientos antivirales cuando se requieran. Pero es imprescindible informar al publico que el consumo de pollo y sus derivados no representa ningún riesgo de infección, aunque se sabe que el consumo de carne cruda de aves infectadas puede favorecer la transmisión del virus en animales silvestres o en cautiverio. En este sentido es importante limitar el movimiento de animales provenientes de áreas donde circulan los virus que de manera potencial pueden causar infecciones en el hombre. También es importante fortalecer la vigilancia en aves migratorias, en particular las acuáticas, y reforzar la vigilancia del tráfico de aves que se utilizan como mascotas, para zoológicos y otros propósitos comerciales.

Otra estrategia para limitar la circulación del virus es a través de la vacunación de aves de granja; sin embargo, la vacunación puede facilitar la selección de virus o limitar su detección. En algunos países asiáticos se utiliza la vacuna que se produce en México (H5N2) y es posible que confiera protección parcial contra el virus H5N1.

México tiene una vigilancia en aves que permite detectar la circulación de virus de alta patogenicidad; además, no compra aves provenientes de países que han informado sobre casos, aunque es posible que el virus de influenza se transporte por medio de aves migratorias o animales que se introducen legal o ilegalmente al país. En este momento lo más importante es limitar la circulación de aves que en potencia puedan estar infectadas con el virus $\mathrm{H} 5 \mathrm{~N} 1$ o con algún otro virus quizá peligroso para el hombre. Algunos países han utilizado una combinación de estrategias para limitar la circulación del virus
H5N1, como la eliminación de aves infectadas o enfermas, la vacunación y el tratamiento de los pacientes.

Otra opción para controlar la infección es a través del uso de medicamentos, por ejemplo los inhibidores de la proteína M2 y/o de la neuraminidasa; sin embargo, los antivirales son efectivos cuando se usan en forma profiláctica o algunos días después de la infección, aunque es posible que sea limitada la utilidad de estos medicamentos en una pandemia; también habrá que considerar la presencia de virus resistentes a los medicamentos.

En caso de que ocurriera una pandemia, se requerirá mas personal médico y enfermeras, infraestructura hospitalaria y de servicios de diagnóstico y atención a los pacientes graves con complicaciones secundarias, particularmente con infecciones respiratorias producto de otros virus respiratorios o bacterias. En una pandemia será difícil limitar la diseminación del virus a través de la transportación aérea, marítima y terrestre; además, puede afectarse la actividad comercial y la de la población en su conjunto, en virtud del potencial cierre de comercios, escuelas y diversos centros de congregación de personas: cines, teatros, clubes, etcétera.

Finalmente, es importante que en México y otros países de Latinoamérica se impulse la investigación básica y aplicada para el estudio de la influenza, se apoye la infraestructura para la producción de vacunas y medicamentos antivirales, se fortalezcan las colaboraciones internacionales y se difunda a la población información veraz basada en hechos científicos.

Dr. Celso Ramos*

\section{Referencias}

I. Lipatov AS, Govorkova EA,Webby RJ, Ozaki H, Peiris M, Guan Y et al. Influenza: Emergence and control (Minireview).JVirol 2004;78:895I-8959.

2. Webster RG. Wet markets- a continuing source of severe acute respiratory syndrome and influenza?. Lancet 2004;363:234-236.

3. Guan Y, Peiris JSM, Lipatov AS, Ellis K, Dyrting KC, Kraus I et al. Emergence of multiple genotypes of $\mathrm{H} 5 \mathrm{NI}$ avian influenza virus in Hong Kong, SAR. Proc Natl Acad Sci USA 2002;99:8950-8955.

4. The World Health Organization Global Influenza Program Surveillance Network. Evolution of H5NI avian influenza viruses in Asia. Emerg Infect Dis 2005; | I:|15|5-|52|.

5 . Webby RT,Webster RG. Are we ready for pandemic influenza? Science 2003;302:1519-1522.

6. Garret L. The next pandemic?. Foreign Affairs 2005;84:4-23.

7. Ostherholm MT. Preparing for the next pandemic. Foreign Affairs 2005;84:24-37.

8. Kresh WB, Cook RA. The human-animal link. Foreign Affairs 2005;84:38-50.

9. Kaiser J. Looking the pandemic. Science 2004;306:392-396.

10. Stohr K, Esveld M. Will vaccines be available for the next influenza pandemic?. Science 2004;306:2195-2196.

II. Fedson DS. Pandemic influenza and the global vaccine supply. Clin Infect Dis 2003;36:1552-1561.

\footnotetext{
* Centro de Investigaciones sobre Enfermedades Infecciosas, Instituto Nacional de Salud Pública.
} 